\title{
Factors related to overweight and obesity in the university population
}

\section{Factores relacionados con sobrepeso y obesidad en población universitaria}

\author{
ALVARADO-SÁNCHEZ，Brenda†*，ZÁRATE-PADRÓN，Alejandra y MACÍAS-PÉREZ，José \\ Roberto, REYES-MUNGUÍA, Abigail
}

Unidad Académica Multidisciplinaria Zona Huasteca. Universidad Autónoma de San Luis Potosí. Romualdo Del Campo 501. Fracc. Rafael Curiel. Ciudad Valles, S.L.P. CP. 79060

ID $1^{\text {st }}$ Author: Brenda, Alvarado-Sánchez / ORC ID: 0000-0002-6077-2665, CVU CONACYT ID: 38716I

ID $1^{\text {st }}$ Coauthor: Alejandra, Zárate-Padrón / ORC ID: 0000-0002-3043-6927, CVU CONACYT ID: 437801

ID $2^{\text {nd }}$ Coauthor: José Roberto, Macías-Pérez, ORC ID: 0000-0001-7925-2494, CVU CONACYT ID: 172982

ID $3^{\text {rd }}$ Coauthor: Abigail, Reyes-Munguía / ORC ID: 0000-0002-2151-7979, CVU CONACYT ID: 46743

DOI: $10.35429 / J S R .2019 .15 .5 .47-53$

Received March 20, 2019; Accepted June 30, 2019

\begin{abstract}
Chronic noncommunicable diseases (CND) and chronic degenerative diseases (CDD) are current events worldwide, affecting the health and quality of life of thousands of people throughout the world. We collected information from 1696 people, 716 men and 940 women in an age range of 17 to 32 years, and performed descriptive statistics to obtain the mean \pm standard deviation of each of the determinations and measurements performed, grouped according to the year of study and by the percentage of alterations in each of the measurements. We found that, despite the national strategies created to combat overweight and obesity, and if a tendency to decrease in the percentage of alterations is found, the difference is not statistically significant, which indicates that reforms are required in the strategies for obtaining better results.
\end{abstract}

Overweight, Obesity, CDD

\begin{abstract}
Resumen
Las enfermedades crónicas no transmisibles (ECNT) y las enfermedades crónico-degenerativas (ECD) son el suceso actual a nivel mundial, afectando la salud y calidad de vida de miles de personas a lo largo del mundo. Se recopiló la información de 1696 personas, 716 hombres y 940 mujeres en un rango de edad de 17 a 32 años, a los cuales se les realizó estadística descriptiva para obtener la media \pm desviación estándar de cada una de las determinaciones y mediciones realizadas, se agruparon de acuerdo al año de estudio y por el porcentaje de alteraciones en cada una de las mediciones. Se encontró que, a pesar de las estrategias nacionales creadas para combatir el sobrepeso y la obesidad, y de encontrarse una tendencia de disminución en el porcentaje de alteraciones, la diferencia no resulta significativa estadísticamente, lo cual indica que se requieren reformas en las estrategias para la obtención de mejores resultados.
\end{abstract}

Sobrepeso, Obesidad, ECD

Citation: ALVARADO-SÁNCHEZ, Brenda, ZÁRATE-PADRÓN, Alejandra y MACÍAS-PÉREZ, José Roberto, REYESMUNGUÍA, Abigail. Factors related to overweight and obesity in the university population. Journal of Social Researches. 2019, 5-15: 47-53

\footnotetext{
*Correspondence to Author (email: balvarado@uaslp.mx)

$\dagger$ Researcher contributing first author.
} 


\section{Introduction}

Chronic non-communicable diseases (NCDs), according to the World Health Organization (WHO), are a series of conditions that occur over a long period, most notably diabetes (WHO, 2016). These diseases are associated with $71 \%$ of annual deaths worldwide and do not distinguish between race, gender, or region of residence. The metabolic risk factors that contribute to the appearance of these diseases are increased blood pressure, overweight, obesity, and hyperglycemia and hyperlipaemia (WHO, 2018).

In addition to NCDs, overweight and obesity are defined by the WHO as an excessive accumulation of body fat, which can be determined by the Body Mass Index (BMI), creating a relationship between the weight and height of the individual analyzed, expressed in $\mathrm{kg} / \mathrm{m} 2$ (WHO, 2018).

Globally, by 2016, 39\% of men and $40 \%$ of women worldwide were overweight, while $11 \%$ of men and $15 \%$ of women aged 18 and over were already obese (WHO, 2018).

According to ENSANUT 2006, in Mexico, $39.9 \%$ of the population was overweight, and $30.8 \%$ was obese in a range between the ages of 18 and 40 (Córdova et al., 2008). By 2014, NCDs in Mexico caused $75 \%$ of all deaths. Also, the increase between the frequency of metabolic syndrome and obesity has been paralleled in Latin American countries, including Mexico (Dávila et al., 2014).

In a bulletin issued by the National Autonomous University of Mexico (UNAM), by 2016 in ENSANUT reports, taking into account adults over 20 years, $75.6 \%$ of women and $69.4 \%$ of men were overweight and obese (De la Cruz, 2018). According to all the information provided above, it is vitally important to evaluate all these factors in order to prevent the appearance of diseases associated with overweight, and thus improve people's quality of life, in addition to observing the behavior of the generations over time in order to assess the effect of national health programs on the affected population.

\section{Methodology}

\section{Study population}

For this study, biochemical and anthropometric data were collected for 2014, 2016, and 2017 generations of new students at the Universidad Autónoma de San Luis Potosí - Unidad Académica Multidisciplinaria Zona Huasteca (UASLP - UAMZH). Information was collected from 1696 students (100\%) with an age range of 17 to 32 years, of which 719 were men $(43.34 \%)$ and 940 women $(56.66 \%)$, who were sectioned into patients who presented some alteration, both in indicators of obesity and biochemical alterations.

\section{Treatment of information}

A database was generated in the Excel program, which included data from the medical history of each patient such as full name, gender, age, weight, height, body mass index (BMI), waist circumference (PCin), and biochemical determinations according to income generation, which were Glucose (Glu), Cholesterol (Col) and Triglycerides (Tgl).

The mean \pm standard deviation was calculated for each of the captured parameters, and a one-way analysis of variance was performed to determine if a statistically significant difference existed, using a p-value of $\leq 0.05$ using the statistical program GraphPad Prism V6.

\section{Results}

Table 1 shows the average concentrations and measurements obtained after the analysis. For the determination of Glu, the average values obtained in the three study groups are within the values considered normal by the American Diabetes Association (ADA) (>105 mg/dL). The analysis was performed to determine if there is a significant difference between the three groups and, it was obtained that for the comparison between 2014 and 2016 the value obtained of $p$ was 0.0010 , for 2014 against $2017 \mathrm{p}<0.0001$ and in 2016 against 2017 the value of $\mathrm{p}$ was $<0.0001$, which indicates that there is a statistically significant difference between the three study groups. 
This decreasing trend can be attributed to the programs implemented by the Federal Government since 2006, at the beginning of the "Checate, mídete, muévete" campaign at the Mexican Social Security Institute (IMSS), which sought to create a culture of surveillance and weight control in the population. Similarly, the "PrevenISSSTE" program was created through the ISSSTE health system, which has the same purpose as the program mentioned above. Following these campaigns, the National Strategy for the Prevention and Control of Overweight, Obesity, and Diabetes was published in 2013, with the aim of detecting cases of overweight and obesity in the population on time and thus provide early care to ensure a better quality of life.

In the case of Col, the NOM-037-SSA22012, For the prevention, treatment, and control of dyslipidemias, mentions that the value taken to determine hypercholesterolemia is > 200 $\mathrm{mg} / \mathrm{dL}$. Table 1 shows the Col concentrations of the groups 2014, 2016 and 2017, in which it is observed that the average values are below this criterion, the analysis was performed to determine significant difference and for the years 2014 vs 2017 a value of $p=0.0008$ was obtained, for 2014 vs 2017 the p-value was $<0.0001$, and for 2016 vs 2017 the p-value was $<0.0001$, thus demonstrating that there is a statistically significant difference between the three study groups. This shows that there is a statistically significant difference between the three study groups.

Similarly, the trend observed in the results described above can be attributed to the good management of health strategies and programs implemented by health institutions to achieve a decrease in diseases associated with overweight.

For Tgl, the values marked by the NOM-037-SSA2-2012, For the prevention, treatment, and control of dyslipidemias, indicate that to determine if hypertriglyceridemia exists, the concentration of $\mathrm{Tgl}$ should not be above $150 \mathrm{mg} / \mathrm{dL}$. In the values observed in Table 1, the average concentration per study group is below 150 $\mathrm{mg} / \mathrm{dL}$.
Similarly, the ANOVA analysis was performed to determine if there was a significant difference between the three study groups. In 2014 vs. 2016 comparison, the pvalue was $>0.05$, which indicates that between these study groups, the difference that exists is not statistically significant. On the contrary, in the comparison of 2014 vs 2017, the value obtained was $\mathrm{p}=0.0148$, and in 2016 vs 2017 , the value of $p=0.0024$, thus observing a statistically significant difference between the study groups. It shows a significant decrease in the average values of the university population from 17 to 32 years old.

In the case of obesity indicators, the analysis was made for BMI. In the groups 2014 vs 2016 and 2014 vs 2017, the p-value was > 0.05 , while for 2016 vs 2017 , the p-value was $=$ 0.0065 , showing the significant difference between the groups studied.

For PCin, the analysis performed gave $\mathrm{p}$ values $>0.05$ for the three groups in both men and women, which shows that there is no statistically significant difference between them.

\begin{tabular}{|c|c|c|c|c|}
\hline & & 2014 & 2016 & 2017 \\
\hline & & mical De & rminations & \\
\hline Glu (r & $\mathrm{g} / \mathrm{dL})$ & $\begin{array}{c}92.4 \pm \\
11.5\end{array}$ & $89.09 \pm 9.89$ & $\begin{array}{c}83.90 \pm \\
9.16\end{array}$ \\
\hline $\mathrm{Col}(\mathrm{n}$ & $\mathrm{g} / \mathrm{dL})$ & $\begin{array}{c}152.8 \pm \\
25.4 \\
\end{array}$ & $\begin{array}{c}138.6 \pm \\
28.19 \\
\end{array}$ & $\begin{array}{c}123.1 \pm \\
23.86 \\
\end{array}$ \\
\hline $\operatorname{Tgl}(\mathrm{n}$ & $\mathrm{g} / \mathrm{dL})$ & $\begin{array}{c}115.9 \pm \\
66.6\end{array}$ & $\begin{array}{c}112.9 \pm \\
59.51\end{array}$ & $\begin{array}{c}97.55 \pm \\
55.49\end{array}$ \\
\hline & & besity In & cators & \\
\hline IMC & $\left.\mathrm{g} / \mathrm{m}^{2}\right)$ & $\begin{array}{c}25.8 \pm \\
12.0\end{array}$ & $24.95 \pm 4.82$ & $\begin{array}{c}24.06 \pm \\
0.83\end{array}$ \\
\hline PCin & Male & $\begin{array}{c}87.84 \pm \\
14.8\end{array}$ & $\begin{array}{c}85.58 \pm \\
13.30\end{array}$ & $\begin{array}{c}86.79 \pm \\
12.23\end{array}$ \\
\hline$(\mathrm{cm})$ & Female & $\begin{array}{c}79.61 \pm \\
13.91\end{array}$ & $\begin{array}{c}81.47 \pm \\
15.35\end{array}$ & $\begin{array}{c}80.57 \pm \\
13.10\end{array}$ \\
\hline
\end{tabular}

Table 1 General characterization of the study population (mean \pm standard deviation)

Table 2 shows the prevalence of alterations in both biochemical determinations and obesity indicators in the total study population. In the case of Glu, by $2014,15.5 \%$ presented serum Glu concentrations above 105 $\mathrm{mg} / \mathrm{dL}$. By 2016, 5.1\% presented this condition and by $2017,1.4 \%$. For Col, the percentage of participants found to be above $200 \mathrm{mg} / \mathrm{dL}$ was $0.0 \%$ in $2014,3.1 \%$ in 2016 and $0.5 \%$ in 2017 . 
For Tgl, in 2014, there was a percentage of alteration of $20.8 \%$, by 2016 this percentage decreased to $17.7 \%$, and by 2017 , the percentage was $11.9 \%$.

As for obesity indicators, for BMI in 2014, there was a percentage of alteration $(\geq 25 \mathrm{~kg} / \mathrm{m} 2)$ of $42.2 \%$, in 2016 , this percentage was maintained, while for 2017 it decreased to $35.5 \%$. In the case of central obesity, determined by PCin, in men, by $201423.9 \%$ of participants had this condition, by $201616.4 \%$, and by 2017 the percentage increased to $28.8 \%$. For this same indicator in the case of women, in $201441.7 \%$ presented this condition, in 2016 increased to $48.8 \%$, and in 2017 decreased to $47.4 \%$. The analysis was performed for statistical significance, obtaining, as a result, a value of $p>0.05$, indicating that there is no statistically significant difference between the groups studied.

According to Radwan et al., 2019 in their study, conducted in a population of the same age range, the indicators of obesity maintain the condition shown in this study, with decreased rates of SP and OP. However, BMI was found to be high.

\begin{tabular}{|c|c|c|c|c|c|c|}
\hline & & & & & & \\
\hline & & iochemic & Determi & tions & & \\
\hline $\begin{array}{c}\text { Glu } \geq 105 \\
\mathrm{mg} / \mathrm{dL}\end{array}$ & $n=263$ & $15=15.5 \%$ & & $\begin{array}{c}25= \\
5.1 \%\end{array}$ & & $\begin{array}{c}8= \\
1.4 \%\end{array}$ \\
\hline $\begin{array}{c}\mathrm{Col} \geq 200 \\
\mathrm{mg} / \mathrm{dL}\end{array}$ & $\mathrm{n}=24$ & $0=0.0 \%$ & $\mathrm{n}=486$ & $\begin{array}{c}15= \\
3.1 \%\end{array}$ & $\mathrm{n}=561$ & $\begin{array}{c}3= \\
0.5 \%\end{array}$ \\
\hline $\begin{array}{c}\mathrm{Tgl} \geq 150 \\
\mathrm{mg} / \mathrm{dL}\end{array}$ & $\mathrm{n}=24$ & $5=20.8 \%$ & & $\begin{array}{c}86= \\
17.7 \%\end{array}$ & & $\begin{array}{c}67= \\
11.9 \%\end{array}$ \\
\hline & & Obesity & Indicato & & & \\
\hline $\begin{array}{c}\text { IMC } \\
\geq 25 \mathrm{~kg} / \mathrm{m}^{2}\end{array}$ & $\mathrm{n}=263$ & $\begin{array}{l}111= \\
42.2 \%\end{array}$ & $\mathrm{n}=486$ & $\begin{array}{c}205= \\
42.2 \%\end{array}$ & $\mathrm{n}=561$ & $\begin{array}{c}99= \\
35.5 \%\end{array}$ \\
\hline $\begin{array}{c}\text { PCin Male } \\
\geq 94 \mathrm{~cm}\end{array}$ & $\mathrm{n}=117$ & $28=23.9 \%$ & $\mathrm{n}=214$ & $\begin{array}{c}36= \\
16.4 \%\end{array}$ & $\mathrm{n}=219$ & $\begin{array}{c}63= \\
28.8 \%\end{array}$ \\
\hline $\begin{array}{l}\text { PCin } \\
\text { Female } \\
\geq 80 \mathrm{~cm}\end{array}$ & $\mathrm{n}=146$ & $61=41.7 \%$ & $\mathrm{n}=283$ & $\begin{array}{c}138= \\
48.8 . \%\end{array}$ & $\mathrm{n}=304$ & $\begin{array}{c}144= \\
47.4 \%\end{array}$ \\
\hline
\end{tabular}

Table 2 Population that presented alteration in biochemical determinations and obesity indicators (percentage \%)

The above information was divided by gender. Table 3 shows the percentages of alterations in men. By 2014, 9.4\% presented a Glu greater than $105 \mathrm{mg} / \mathrm{dL}$; in 2016 this percentage decreased to $6.6 \%$, and in 2017 the percentage was $1.31 \%$. In the case of Col, in 2014 and $20170.0 \%$ of the participants presented hypercholesterolemia, while in 2016 $3.3 \%$ did. For $\mathrm{Tgl}$, in $201410.0 \%$ of the participants presented hypertriglyceridemia, while in $201622.6 \%$ showed this condition; however, by 2017 this percentage decreased to $10.8 \%$.
As for obesity indicators, BMI decreased from 2014 (46.1\%) to 2017 (34.2\%). When the analysis was performed to determine whether there was a statistically significant difference, the $\mathrm{p}$-value obtained was $>0.05$ in the comparison of the three groups, showing that there is no difference in any of the determinations and indicators. The prevalence of overweight and obesity in the young adult population is not exclusive to the Mexican population. Azab et al., in 2019, describe a $20.5 \%$ prevalence of overweight in young adult women between 19 and 25 years of age belonging to the University of Jouf in Saudi Arabia, thus showing the importance of the problem at a global level.

It is worrying to note that the proportions of the population affected by overweight or obesity remain constant in young adult subjects. This situation is worrying since both overweight and obesity are relevant precedents for chronic-degenerative diseases such as diabetes, dyslipidemia, and coronary disease, among others, which are presumed to appear at an early age in the groups studied, given the premature appearance of overweight and obesity.

In addition to the inherent problem of satisfying the health care needs of the affected populations, the economic burden that this represents on the family economy and public spending on health, leads to emerging programs for the prevention of overweight and obesity in the young adult population, as a way of avoiding overloading the health system with patients with diseases associated with these conditions.

Moores et al., in 2019, describe an increase in the BMI of the population from Australia and Macau as a function of age. Therefore, it is assumed that there will be an increase in the BMI of the study subjects included in this report in the coming years and, therefore, the early appearance of chronicdegenerative diseases such as diabetes, hypertension, cardiovascular diseases, etc. The appearance of obesity is multifactorial; Savas et al., in 2019, describe a high prevalence of hormonal factors related to hypothyroidism, presence of polycystic ovary syndrome, high birth weight, early menarche, among others, as important determinants for high BMI in subjects of $41.3 \pm 14.2$.

ALVARADO-SÁNCHEZ, Brenda, ZÁRATE-PADRÓN, Alejandra y MACÍAS-PÉREZ, José Roberto, REYES-MUNGUÍA, Abigail. Factors related to overweight and obesity in the university population. Journal of Social Researches. 2019 
However, the WHO considers that the fundamental cause of overweight is the imbalance between the calories consumed and those spent, which is associated with an excessive intake of high-calorie and high-fat foods, as well as the marked sedentariness associated with new forms of work and transport. Therefore, one of the most critical measures for the control of overweight and obesity is the implementation of healthy eating plans, as well as constant exercise routines.

\begin{tabular}{|c|c|c|c|c|c|c|}
\hline \multicolumn{7}{|c|}{$\begin{array}{c}2014 \\
\text { Biochemical Determinations }\end{array}$} \\
\hline $\begin{array}{c}\text { Glu } \geq 105 \\
\mathrm{mg} / \mathrm{dL}\end{array}$ & $\mathrm{n}=117$ & $\begin{array}{c}11= \\
9.4 \%\end{array}$ & \multirow{3}{*}{$\mathrm{n}=212$} & $\begin{array}{l}14= \\
6.6 \%\end{array}$ & \multirow{3}{*}{$\mathrm{n}=304$} & $\begin{array}{c}4= \\
1.31 \%\end{array}$ \\
\hline $\begin{array}{c}\mathrm{Col} \geq 200 \\
\mathrm{mg} / \mathrm{dL}\end{array}$ & $\mathrm{n}=10$ & $0=0.0 \%$ & & $7=3.3 \%$ & & $\begin{array}{c}0= \\
0.0 \%\end{array}$ \\
\hline $\begin{array}{l}\mathrm{Tgl} \geq 150 \\
\mathrm{mg} / \mathrm{dL}\end{array}$ & $\mathrm{n}=10$ & $\begin{array}{c}1= \\
10.0 \%\end{array}$ & & $\begin{array}{c}48= \\
22.6 \%\end{array}$ & & $\begin{array}{c}33= \\
10.8 \%\end{array}$ \\
\hline \multicolumn{7}{|c|}{ Obesity Indicators } \\
\hline $\begin{array}{c}\mathrm{IMC} \geq 25 \\
\mathrm{~kg} / \mathrm{m}^{2}\end{array}$ & $\mathrm{n}=117$ & $\begin{array}{c}59= \\
46.1 \%\end{array}$ & $\mathrm{n}=212$ & $\begin{array}{c}89= \\
42.0 \% \\
\end{array}$ & $\mathrm{n}=304$ & $\begin{array}{r}104= \\
34.2 \% \\
\end{array}$ \\
\hline
\end{tabular}

Table 3 Prevalence of alteration in biochemical determinations and indicators of obesity in men (percentage \%)

Table 4 shows the percentage of alterations in women, for Glu in $20142.7 \%$, in 2016, the percentage increased to $3-9 \%$, and in 2017 it decreased again to $1.5 \%$. For Col, in $20140.0 \%$ presented alteration, in $20162.9 \%$ and in 2017 the percentage decreased to $1.2 \%$. As for Tgl, in 2014, 28.6\% presented Tgl concentrations above $150 \mathrm{mg} / \mathrm{dL}$, decreasing in 2016 to $13.4 \%$ and in 2017 to $13.2 \%$.

Finally, for obesity indicators, BMI in 2014 showed a percentage of alteration of $39.0 \%$, in 2016 it increased to $41.0 \%$, and in 2017 it decreased again to $37.0 \%$. In the analysis of statistical significance, the value obtained for $\mathrm{p}$ was $>0.05$, showing that there is no statistically significant difference between the study groups.

\begin{tabular}{|c|c|c|c|c|c|c|}
\hline & \multicolumn{2}{|c|}{2014} & 2 & 16 & \multicolumn{2}{|c|}{2017} \\
\hline \multicolumn{7}{|c|}{ Biochemical Determinations } \\
\hline $\begin{array}{c}\text { Glu } \geq 105 \\
\mathrm{mg} / \mathrm{dL}\end{array}$ & $n=146$ & $\begin{array}{c}4= \\
2.7 \%\end{array}$ & \multirow{3}{*}{$\mathrm{n}=283$} & $\begin{array}{c}11= \\
3.9 \%\end{array}$ & \multirow{3}{*}{$\mathrm{n}=257$} & $4=1.5 \%$ \\
\hline $\begin{array}{c}\mathrm{Col} \geq 200 \\
\mathrm{mg} / \mathrm{dL}\end{array}$ & $\mathrm{n}=14$ & $\begin{array}{c}0= \\
0.0 \%\end{array}$ & & $8=2.9 \%$ & & $3=1.2 \%$ \\
\hline $\begin{array}{c}\mathrm{Tgl} \geq 150 \\
\mathrm{mg} / \mathrm{dL}\end{array}$ & $\mathrm{n}=14$ & $\begin{array}{c}4= \\
28.6 \%\end{array}$ & & $\begin{array}{c}38= \\
13.4 \%\end{array}$ & & $\begin{array}{c}34= \\
13.2 \%\end{array}$ \\
\hline \multicolumn{7}{|c|}{ Obesity Indicators } \\
\hline $\begin{array}{c}\mathrm{IMC} \geq 25 \\
\mathrm{~kg} / \mathrm{m}^{2}\end{array}$ & $n=146$ & $\begin{array}{c}57= \\
39.0 \%\end{array}$ & $\mathrm{n}=283$ & $\begin{array}{c}116= \\
41.0 \%\end{array}$ & $\mathrm{n}=257$ & $\begin{array}{c}95= \\
37.0 \%\end{array}$ \\
\hline
\end{tabular}

Table 4 Prevalence of alteration in biochemical determinations and indicators of obesity in women (percentage \%)
As shown in table 1, it can be observed that there is a tendency to decrease in some of the determinations and measures carried out; however, in tables 2, 3 and 4 no statistically significant difference was found between the percentages of alterations among the groups studied; some indicators such as BMI remain high, thus observing that the national strategies and plans being implemented to combat and prevent the appearance of NCD and DCS are not fully functional.

Based on reports from the Organization for Economic Cooperation and Development (OECD) in 2015, Mexico was in second place in terms of obesity, determined by calculating the BMI of different countries with a population percentage of over $30.0 \%$ (BBC, 2018).

\section{Conclusions}

The health programs implemented since 2013 with the restructuring of the national strategy for the prevention and control of overweight, obesity, and diabetes, have given favorable results in the trend of decreasing new cases of diabetes, dyslipidemias and overweight and obesity; however, no significant difference has been found between the percentage of participants with these types of alterations.

Although there are still measures to be taken, it is a good start to decrease the incidence of chronic non-communicable diseases in vulnerable populations, such as young adults of university age, who are exposed to forced changes in their diet and eating habits according to the study load they are facing.

However, the efforts of government organizations have not been sufficient to decrease or at least control the high prevalence of overweight and obesity. Even more worrying is the fact that this is occurring at an increasingly younger age. The cost that this represents for any health system is unsustainable in the medium term, so it is advisable to increase efforts to stop the progress in terms of overweight and obesity figures. This requires a joint effort between the government, health specialists, and the general population. 
For the control of overweight and obesity, a change in the patient's life habits is required, and the patient should be the first to admit the health problem he or she is facing. In the particular case of the population studied in this research, it becomes more relevant since being young adults, they perceive themselves as healthy, and they have no intention of making changes in their lifestyle. Besides, this population is subjected to high levels of stress during their university education, which invariably increases their BMI.

Another situation that should motivate the implementation of active awareness campaigns of the problem that overweight and obesity represent in the young adult population is the fact that these subjects begin their productive lives, and in case of maintaining their BMI or even increasing it, they are potential candidates to develop chronicdegenerative diseases, which at a certain time are disabling, so that their working life is shortened, affecting the family and national economy.

\section{Acknowledgments}

To the Bq. Marlen Rodríguez Espino and Mtro. Juan Del Toro Herrera, staff of the Laboratory of Biomedical Sciences and the Laboratory of Biomedical Research of the UASLP - UAMZH respectively, for the technical support provided for this work.

\section{References}

Córdova-Villalobos, José Ángel, BarrigueteMeléndez, Jorge Armando, Lara-Esqueda, Agustín, Barquera, Simón, Rosas-Peralta, Martín, Hernández-Ávila, Mauricio, León-May, María Eugenia de, Admon, Lic, \& AguilarSalinas, Carlos A. (2008). Las enfermedades crónicas no transmisibles en México: sinopsis epidemiológica y prevención integral. Salud Pública de México, 50(5), 419-427.

Dávila Torres, J., González Izquierdo, J. J., \& Barrera Cruz, A. (2015). Panorama de la obesidad en México. Rev Med Ins Mex Seguro Soc, 240-9.

De la Cruz, Lizbeth. (2018). Sobrepeso y Obesidad en la UNAM. Retrieved from: https://www.c3.unam.mx/pdf/boletines/Boletin 23_2018.pdf
El Azab, E. F., Elwasefy, S. A., Shaban, H. E., Mohamed, F. A., \& Alsharari, A. H. (2019). Obesity related risk factors among the saudi female students in Jouf University. Journal of Health, Medicine and Nursing, 4(1), 38-49.

Moores, C. J., Ke, L., Mason, R. S., Gill, T. P., Mpofu, E., Ho, J., Dibley M.J. \& Brock, K. E. (2019). Body Mass Index Increases With Ageing and Risk Factors for Overweight/Obesity in a Representative Macau Population. Asia Pacific Journal of Public Health, 31(2), 167-172

NORMA Oficial Mexicana NOM-008-SSA32017, Para el tratamiento integral del sobrepeso y la obesidad.

NORMA Oficial Mexicana NOM-037-SSA22012, Para la prevención, tratamiento y control de las dislipidemias.

News, B. (07 de abril de 2018). ¿Es realmente México el país más obeso del mundo? Retrieved from BBC News: https://www.bbc.com/mundo/noticias-americalatina-43664557

Organización Mundial de la Salud (2016). Enfermedades no transmisibles. Retrieved from:

https://www.who.int/topics/noncommunicable_ diseases/es/

Organización Mundial de la Salud (2018). Enfermedades no transmisibles. Datos y cifras. Retrieved from: https://www.who.int/es/newsroom/fact-sheets/detail/noncommunicablediseases

Organización Mundial de la Salud (2018). Obesidad y sobrepeso. Datos y cifras. Retrieved from: https://www.who.int/es/news-room/factsheets/detail/obesity-and-overweight

Radwan, H., Hasan, H., Ismat, H., Hakim, H., Khalid, H., Al-Fityani,, L., Mohammed, R. and Ayman, A. (2019). Body Mass Index Perception, Body Image Dissatisfaction and Their Relations with Weight-Related Behaviors among University Students. In: International Journal of Environmental Research and Public Health. 2-11. 
Savas, M., Wester, V. L., Visser, J. A., Kleinendorst, L., van der Zwaag, B., van Haelst, M. M., van Den Akker, E.L.T. \& van Rossum, E. F. (2019). Extensive Phenotyping for Potential Weight-Inducing Factors in an Outpatient Population with Obesity. Obesity Facts, 12(4), 369-384.

Secretaria de Salud (2013). Estrategia Nacional para la Prevención y el Control del Sobrepeso, la Obesidad y la Diabetes. 1st ed. Retrieved from:

https://www.gob.mx/cms/uploads/attachment/fi le/276108/estrategia_sobrepeso_diabetes_obesi dad.pdf

Secretaria de Salud (2014). Prevención y control de la Obesidad y Riesgo Cardiovascular. Programa Sectorial de Salud 2013-2018. Retrieved from: http://www.cenaprece.salud.gob.mx/descargas/ pdf/PAE_PrevencionControlObesidadRiesgoCa rdiovascular2013_2018.pdf 